\title{
NONINVASIVE DETECTION OF CORONARY ARTERY DISEASE - CHALLENGES FOR PREVENTION OF DISEASE AND CLINICAL EVENTS
}

\author{
Protásio Lemos da Luz, Paulo José Bertini, and Desiderio Favarato
}

Luz PL da, Bertini PJ, Favarat D. Noninvasive detection of coronary artery disease - challenges for prevention of disease and clinical events. Clinics. 2005;60(5):415-28.

\begin{abstract}
Atherosclerosis is a chronic inflammatory disease that affects essentially all arterial beds including the aorta, coronaries, carotids, and peripheral arteries. It is the main cause of death in the western hemisphere, due to cardiovascular syndromes such as myocardial infarction, heart failure, and cerebrovascular accidents.

Very substantial economic and human resources have been used on treatments of its complications, including imaging studies, coronary bypass surgery, catheter interventions, pacemakers, and medical treatments. Treating complications, however, are remedial actions.

A better alternative is to prevent the development of atherosclerosis, or at least to identify patients who are at risk of acute events and intervene before they occur.

The aims of this review are to discuss the predictive value of traditional and emerging risk factors, as well as the role of noninvasive diagnostic methods for coronary atherosclerosis, including exercise stress test, echo stress test, duplex ultrasound, computed tomography, and magnetic resonance.

A combination of serum biomarkers and noninvasive approaches is of practical utility for identifying early disease. It is to be expected that future developments will soon perfect our ability to identify the vulnerable patient and allow a more individualized approach.
\end{abstract}

KEYWORDS: Atherosclerosis. Lipids. Coronary disease. Diagnostic tests. Diagnostic imaging, cardiovascular.

Atherosclerosis is a chronic inflammatory disease that affects essentially all arterial beds including the thoracic and abdominal aorta, coronary arteries, carotids, peripheral, renal and mesenteric arteries. It results from a complex interaction between genetic and environmental factors that causes the arterial wall to respond to inflammatory stimuli through the actions of endothelial cells, smooth muscle cells, inflammatory cells, and platelets. ${ }^{1}$ These produce a large variety of substances such as growth factors, cytokines, reactive oxygen species, enzymes, signaling factors that profoundly alter the arterial wall structure, and

Atherosclerosis Unit, Heart Institute (INCOR), Hospital das Clínicas, Faculty of Medicine, University of São Paulo - São Paulo/SP, Brazil.

Email: daluzp@incor.usp.br

Received for publication on June 07, 2005.

Accepted for publication on July 28, 2005. finally lead to the development of the atherosclerotic plaque..$^{2-4}$ The plaque is composed of varying amounts of smooth muscle cells; monocyte-derived macrophages; T lymphocytes; cholesterol; cholesteryl esters; phospholipids; and extracellular connective tissue. This ensemble forms the extracellular matrix including collagen, proteoglycans, and the pericellular matrix formed by fibronectin and elastic fibers. ${ }^{5-7}$ The plaque eventually progresses to the point of obstructing the arterial lumen, reducing blood flow, and causing several clinical manifestations. A detailed description of plaque formation and evolution is beyond the scope of this article.

Atherosclerotic cardiovascular disease is the main cause of death in the western hemisphere, including in Brazil. ${ }^{8}$ For the last decades, the principal focus of treatment and investigation has been its complications, notably myocar- 
dial infarction, angina, sudden death, and heart failure. Very substantial economic and human resources, including imaging studies, catheterizations, coronary bypass surgery, catheter interventions, pacemakers, and medical treatments, have been used for the diagnosis and treatment of these complications. In spite of undeniable progress in all these areas with improved overall outcomes, treating complications of a disease is in fact a medical failure; we are acting after the events A better alternative would be to prevent the development of the basic disease, i.e., atherosclerosis, or at least to identify those patients who are at risk of an acute event and to intervene before damage occurs ffor instance, ahead of the left ventricular dysfunction that follows a myocardial infarction.

Identifying causative factors of the primary disease is the fundamental principle of so-called primary prevention. The rational basis for the application of the principle lies in the ability to recognize individuals who are at risk for development of the disease, as well as those who are at risk for complications; the logical consequence is the customized use of effective therapeutic approaches.

In order to apply such a preventive approach, a basic knowledge of the nature of atherosclerosis is essential. Therefore, some pertinent features of atherosclerosis relevant to its prevention shall be highlighted.

First, atherosclerosis begins very early in life. In fact, in some instances the genetic determinants of atherosclerosis are present from the moment the ovum is fertilized by a spermatozoid, and the genes of the parents are mutually influenced, composing a new human being. However, this is the fate of a minority; it is estimated that only about $20 \%$ of cases of atherosclerosis are genetically determined. ${ }^{9,10}$ That atherosclerosis appears in infants, adolescents, and young adults, both male and females, blacks and whites, has been documented in several necropsy studies of young persons who died of violent death due to war wounds, accidents, suicides, or homicides. ${ }^{11-15}$ These individuals were asymptomatic, and their mean age was less than 30 years. In the Bogalusa study,$^{13}$ the degree of atherosclerosis involvement in the aorta and the coronary arteries was directly proportional to the presence of classic risk factors. Thus, the development of atherosclerosis is an early phenomenon in humans although its clinical manifestation may only occur decades later.

Second, the development of atherosclerotic plaques begins in the arterial wall and progresses slowly in such way that for a long period of time the arterial lumen in not significantly affected; consequently blood flow may be normal even under conditions of increased oxygen demand, such as intense exercise. Hence no ischemic symptoms may occur. This was initially documented by Glagov et $\mathrm{al}^{16}$ and termed positive arterial remodeling; in the initial phases of plaque formation there is a thickening of the arterial wall and external expansion with maintenance of the lumen. In this phase, conventional coronary arteriography shows no luminal abnormalities or only arterial irregularities. For a certain time in the past, this finding was thought to indicate absence of atherosclerosis; we now know that is not so. Arterial remodeling explains the long asymptomatic period so often seen in patients with coronary artery disease.

Third, lesions that are not hemodynamically significant, e.g., those causing $<70 \%$ stenosis, may suddenly become unstable, suffer rupture, and cause partial or total occlusions precipitating an acute coronary crisis. ${ }^{17}$ Many factors may contribute to this phenomenon, including structural characteristics of the plaque, endothelial erosions, inflammation, and thrombosis..$^{18}$ Therefore, having a plaque that is not flow-limiting does not necessary guarantee an event-free clinical course. This is corroborated by the finding that clinical coronary events are acute in two thirds of cases, while stable angina represents only one third. In addition, in $65 \%$ of acute coronary syndrome cases angiographic studies have documented previous lesions or the residual lesion in the culprit vessel which were less than $50 \% .{ }^{19}$ The frequency of the destabilization phenomenon, as well as the fact that interventions such as coronary surgery or angioplasty are usually associated with higher complication rates than elective ones, highlights the importance of identifying patients with potentially unstable syndromes. Ideally all interventions should be elective.

Fourth, about $40 \%$ of patients in the fifth decade of their lives with documented coronary artery disease do not have classic risk factors..$^{20}$ Therefore, on one hand, the presence of classic risk factors does confer a greater risk of atherosclerosis; on the other, their absence is no guarantee that the disease will not be present. More recent understanding of the pathophysiology of atherosclerosis has shed some light into this question; thus, the inclusion of inflammation, oxidative stress, endothelial dysfunction, and other novel risk factors may help to better judge the interaction among all risk factors and atherosclerosis.

Fifth, atherosclerosis is a systemic disease. The Framingham study ${ }^{21}$ showed that patients presenting myocardial infarction, cerebral vascular accident, heart failure, or peripheral vascular insufficiency as their first manifestation would, in the following 10 years, manifest disease in another vascular territory in proportions varying from $16 \%$ to $50 \%$, both for men and women. In addition, secondary prevention studies with statins have systematically documented reductions of cardiac events, as well as reductions in stroke and intermittent claudication; this clinical observation makes biological sense since the basic patho- 
physiological mechanisms of atherosclerosis are the same, although regional variations are noted due to specific characteristics of the particular vascular beds. This feature of atherosclerosis makes it possible to analyze peripheral vessels, such as the carotid and brachial arteries, and draw meaningful inferences regarding what may occur in the coronary circulation, as has been shown for endothelial function $^{22}$ and carotid intima-media thickness. ${ }^{23}$ Noninvasive vascular analysis has taken advantage of this fact, as will be discussed later.

So far, the most frequently used method to predict risk has been the Framingham score ${ }^{24,25}$ and the European risk score. ${ }^{26}$ These take into account the presence of classic risk factors, EKG findings, and pertinent clinical data. Although of great practical value, these systems are destined to predict risk, not the presence of disease in itself. In addition, since a considerable number of patients do not exhibit classic risk factors, this subset of individuals is not properly investigated. In addition, the presence of risk factors by itself does not mean that any given individual will develop the disease. Also, a long time lag between the documentation of a risk factor and the actual appearance of disease may occur; for instance, if the time lag is long, treating a patient for the presence of only 1 or 2 risk factors may indeed represent a significant decision problem. Hence, the search for methods of early detection of coronary disease may be justified. When the disease is detected in its early phases, a customized treatment may be proposed. But if no disease is present, the aggressive treatment of 1 risk factor may not be justified. Hence, an individualized approach should be aimed at, for; it would allow safer and eventually less costly treatments.

\section{NONINVASIVE DETECTION OF ATHEROSCLEROSIS}

Clinical information is highly relevant for the recognition of atherosclerosis; thus, the typical history of angina, intermittent claudication, or a past coronary event, such as myocardial infarction, indicates with great probability the presence of the disease. The Framingham study ${ }^{27}$ established the validity of hypercholesterolemia, smoking, age, male sex, diabetes, obesity, sedentariness, and arterial hypertension, among others, as major determinants of future cardiovascular events, as to be later discussed. Diabetes in particular has received special recent attention, ${ }^{28}$ since its mere presence has been found to be as strong a predictor of events as a previous myocardial infarction. In parallel, the metabolic syndrome represented by insulin resistance, obesity, hypertension, and atherogenic dyslipidemia represents a major cause of atherosclerosis. ${ }^{29}$
Physical examination is very often entirely normal in atherosclerotic individuals, especially in the early phases of the disease. However, some findings, such as a carotid murmur or the absence of peripheral pulses, carry a strong predictive power.

Some specific laboratory data have predictive value for atherosclerosis development. Hypercholesterolemia, specifically elevated low-density lipoprotein, is the best known and also the most widely tested lipid abnormality in primary and secondary prevention studies. ${ }^{30}$ It is worth considering lowdensity lipoprotein heterogeneity. Small, dense low-density lipoprotein particles are more atherogenic than large, buoyant low-density lipoprotein particles. ${ }^{31}$ The oxidation of lowdensity lipoprotein also increases its atherogenicity. Lowdensity lipoprotein contains apolipoprotein (apo) B-100, which may be also atherogenic. Furthermore, some particles are larger and rich in triglycerides (large very-low-density lipoprotein), whereas others are smaller and rich in cholesteryl esters (small very-low-density lipoprotein, intermediate-density lipopoprotein). It is now known that remnant lipoproteins containing apo C-III are highly atherogenic, as is lipoprotein(a), another member of the apo B-100 group. ${ }^{32}$ Based on numerous large and well-designed clinical trials that followed thousands of patients for many years, it can be said that the benefits of lipid lowering therapy are now demonstrated beyond any reasonable doubt. These benefits extend to both men and women of all ages. ${ }^{30}$

Low levels of high-density lipoprotein are also recognized as an independent risk factor. ${ }^{33}$ We have shown that in healthy individuals in whom the only abnormality was a low level of high density lipoprotein, the endothelial-dependent arterial relaxation was significantly impaired and that this alteration could be reversed by niacin treatment. ${ }^{34}$ These individuals also had a decreased plasma clearance of chylomicron remnants; the two abnormalities facilitate atherosclerosis development and may explain the known elevated susceptibility for early atherosclerosis of patients with low levels of high-density lipoprotein.

Hypertriglyceridemia has also been analyzed. According to a meta-analysis of 17 prospective trials, hypertriglyceridemia is an independent risk factor for cardiovascular disease. ${ }^{35}$ The PROCAM study for instance found a significant relationship between hypertriglyceridemia and coronary artery disease risk, independent of low- and highdensity lipoprotein levels. ${ }^{36}$

Remnant lipoproteins derived from chylomicrons and/ or very low-density lipoprotein also promote atherogenesis and correlate especially with the progression of atherosclerosis. ${ }^{37}$ Both remnant cholesterol and remnant triglycerides were found to be increased in diabetic men and women compared with nondiabetics. ${ }^{38}$ 
We have also analyzed the triglycerides/high-density lipoprotein ratio in relation to the precocity of coronary artery disease detection in 495 patients with documented coronary artery disease. ${ }^{39}$ Taking triglycerides of $150 \mathrm{mg} /$ $\mathrm{dL}$ and high-density lipoprotein of $40 \mathrm{mg} / \mathrm{dL}$ as normal values, a triglycerides/high density lipoprotein ratio of 3.75 was reckoned to be a normal value ${ }^{39}$ It was subsequently shown that values above 4.0 coincide with higher proportions of small low-density lipoprotein particles in human plasma ${ }^{40}$ which have already been demonstrated to be particularly atherogenic. Although all lipid variables were associated with coronary artery disease, the strongest associations were with triglycerides and the triglycerides/HDL ratio above 3.75 , especially in patients younger than 50 years of age. In addition, we found in 274 patients subjected to diagnostic coronary angiography that the extent of coronary disease evaluated through the Friesinger score ${ }^{41}$ best correlated with the triglycerides/high density lipoprotein ratio. ${ }^{42}$ Thus, a triglyceride/high density lipoprotein ratio $>4.0$, not only correlates with precocity of coronary artery disease as clinically detected but also with more extensive coronary lesions. It may hence be a useful surrogate for atherosclerosis assessment.

Less commonly used, lipoprotein(a) may also be of value. Lipoprotein(a) is structurally similar to low density lipoprotein in protein and lipid composition. ${ }^{32}$ Retrospective casecontrol studies found a strong association between elevated lipoprotein(a) levels and coronary artery disease; however it should be noted that only 9 out of 13 prospective studies found lipoprotein(a) to be an independent risk factor for coronary artery disease. There is no clinical trial demonstrating that lowering lipoprotein(a) levels decreases coronary artery disease risk. Thus the value of lipoprotein(a) for atherosclerosis prediction remains uncertain.

\section{NEW RISK FACTORS FOR ATHEROSCLEROSIS}

The inflammatory nature of atherosclerosis may be evidenced through easily measurable plasma components that can be, and have been proposed to reflect not only the presence of the disease itself, but also to indicate its clinical course, complications, and prognosis. ${ }^{43-50}$ High sensitivity C-reactive protein is the most used of these parameters. It has -additive value for predicting coronary artery disease risk beyond the classic risk factors. ${ }^{43}$ In prospective studies, healthy men and women with increased baseline levels of C-reactive protein were at increased risk for future coronary artery disease. ${ }^{44}$ Subclinical coronary calcification was also associated with increased C-reactive protein, in men and women ${ }^{45}$ and was significantly elevated in patients with coronary disease who died suddenly. It also correlates with immunohistochemical staining intensity and numbers of inflammatory cells in thin cap atheroma. ${ }^{46}$ Furthermore, one study reported that C-reactive protein is a risk factor that is independent of traditional risk factors, such as total cholesterol, high density lipoprotein cholesterol, age, smoking, body mass index, and blood pressure in women. ${ }^{47} \mathrm{~A}$ proof of concept argument can be the results of lipid-lowering trials in patients with recent acute coronary syndromes. In the PROVE-IT ${ }^{48}$ study, patients with a recent myocardial infarction were treated with either pravastatin or atorvastatin and followed up for a mean of 24 months; regardless the statin used. The reductions in recurrent myocardial infarction were greater when low-density lipoprotein $<70 \mathrm{mg} / \mathrm{dL}$ and C-reactive protein $<2 \mathrm{mg} / \mathrm{L}$ were achieved simultaneously by statin therapy than when those two values were above such limits. When low-density lipoprotein was $<70 \mathrm{mg} / \mathrm{dL}$ but C-reactive protein $>2 \mathrm{mg} / \mathrm{L}$, or vice-versa, an intermediate reduction in recurrent myocardial infarction was observed. Thus lowering lipid levels and combating inflammation, both resulting from statin therapy, are comparably important for prevention of complications post acute coronary events.

A caveat regarding the routine use of C-reactive protein for risk prediction is warranted. C-reactive protein is a nonspecific marker of inflammatory diseases: it can be elevated in practically every inflammatory disease, such as rheumatic, chronic bacterial, or immunologic conditions. Nevertheless, the optional use of C-reactive protein to guide physicians in identifying patients without known cardiovascular disease who may be at higher risk than estimated by major risk factors alone was recently recommended by the American Heart Association. ${ }^{49}$ The rationale is that the additional information may guide the clinician in deciding for further evaluation, such as functional tests or even therapy.

Lipoprotein-associated phospholipase A2 has been studied. Lipoprotein-associated phospholipase A2 is an enzyme that catalyzes the hydrolysis of oxidized phospholipids, generating 2 bioactive products that can potentiate atherogenesis: lysophosphatidylcholine and nonesterified fatty acid moieties. ${ }^{3,4}$ Examining the association of lipoproteinassociated phospholipase A2 mass and activity with calcified coronary plaques in 266 cases of young adults and comparing to 266 controls, the authors of the Cardia study ${ }^{51}$ found that lipoprotein-associated phospholipase A2 was significantly higher in the cases than in the controls. They concluded that the enzyme is a useful marker for subclinical cardiovascular risk. Further studies are necessary, but lipoprotein-associated phospholipase A2 is a potential therapeutic target.

Homocysteine is the product of demethylation of methionine; remethylation and trans-sulfuration are critical 
steps in its degradation. Hyperhomocysteinemia is generally considered a contributing factor in systemic atherosclerosis, cerebrovascular disease, and peripheral vascular disease. Several case-control and cohort studies have linked hyperhomocysteinemia with coronary artery disease risk. In a Brazilian population of 236 patients, men and women, subjected to diagnostic coronary angiography, we recorded a number of significant points: (i) homocysteine levels were higher in those with than in those without coronary artery disease; (ii). multivariate analysis showed hyperhomocysteinemia to be an independent risk factor for coronary artery disease with an odds ratio of 2.48 (CI 95\% 1.026.14); (iii) an inverse relationship between homocysteine levels and folic acid was observed; (iv) patients with more advanced coronary lesions as determined by the Friesinger method had a higher frequency of hyperhomocysteinemia. ${ }^{52}$ Our data are consistent with other studies, such as the Framingham Heart Study ${ }^{53}$ and the Atherosclerosis Risk in Communities (ARIC) study. ${ }^{54}$

\section{B-TYPE NATRIURETIC PEPTIDE}

Natriuretic peptides are hormones involved in volume homeostasis and have been found to be increased in ventricular dysfunction. There are suggestions that they may have prognostic significance in apparently healthy persons. Thus, in 3,346 persons without heart failure included in the Framingham Heart Study, plasma B-type natriuretic peptide and N-terminal pro-atrial natriuretic peptide were examined regarding (a) the risk of death from any cause, (b) a first major cardiovascular event, (c) heart failure, (d) atrial fibrillation, (e) stroke or transient ischemic attack, and (f) coronary heart disease. ${ }^{55}$ Even adjusting for cardiovascular risk factors, each increment of one standard deviation in B-type natriuretic peptide levels was associated with a $27 \%$ increase in the risk of death $(P<.009)$, a $28 \%$ increase in the risk of a first cardiovascular event $(P<.03)$, and a $77 \%$ increase in the risk of heart failure $(P<.001)$. The mean follow-up was 5.2 years. The investigators concluded that plasma B-type natriuretic peptide levels predict the risk of death and cardiovascular events independent of traditional risk factors. ${ }^{55,56}$ Further studies are needed to establish the true value of this parameters in terms of risk prediction in asymptomatic individuals.

\section{SOLUBLE CD40 LIGAND}

The CD40-CD40 ligand system is present in leukocytic and nonleukocytic cells, including endothelial and smoothmuscle cells and on activated platelets. ${ }^{57}$ The CD40 ligand also occurs as soluble CD40 ligand (sCD40L), which is proinflammatory for endothelial cells and promotes tissue factor expression on monocytes and endothelial cells. Evidence indicates that the CD40 ligand plays key roles in atherosclerosis development, progression, and complications, even in apparently healthy individuals. For instance, the Orbofiban in Patients with Unstable Coronary Syndromes-Thrombolysis In Myocardial Infarction-16 (OPUS-TIMI-16) found that elevated plasma levels of sCD40L identify patients at increased risk of death and recurrent myocardial infarction independent of other predictive variables, including troponin I and C-reactive protein. ${ }^{58}$

Additional investigation is warranted to define the practical role of soluble CD40 ligand in primary prevention.

\section{FRAMINGHAM RISK SCORE}

The Framingham risk score is certainly very popular and useful. It is a global risk score based on traditional risk factors such as age, sex, smoking, blood pressure, diabetes, arterial hypertension, and cholesterol values. According to the Framingham risk score, individuals are ranked into low-, intermediate-, and high-risk groups based on their chances of having events in 10 years. The low-risk group has less than $6 \%$ risk over 10 years, the intermediate-risk group, $6 \%$ to $20 \%$ risk over 10 years, and the high-risk group, equal to or higher than $20 \%$ risk over 10 years. Risk for the latter group is equivalent to those for patients with stable established coronary artery disease..$^{59}$ Greenland et al, ${ }^{59}$ analyzed the North American adult population and estimated that $35 \%$ are in the low-risk group, $40 \%$ in the intermediate-risk group, and $25 \%$ in the high-risk group. This score system facilitates identification of patients at different risk levels and also has implications for counseling and treatment. The absence of any major risk factor identifies individuals at very low risk, while the traditionally major risk factors account for $50 \%$ to $80 \%$ of subsequent cardiovascular events in highrisk patients. ${ }^{60,61}$ The high-risk group-i.e., risk greater than $20 \%$ for 10 years-probably benefits from aggressive risk factor reduction such as a combination of healthy eating and exercise plus aggressive medical therapy, while patients at low risk require essentially advice regarding healthy lifestyles. However, the intermediate group represents the greatest challenge for treatment decisions and should always be evaluated carefully and individually. ${ }^{62}$

The European Risk Score ${ }^{25}$ is based on similar criteria and is therefore equivalent for practical purposes. A major limitation of this risk score system is that a significant number of individuals in the fifth and sixth decade of life with documented coronary artery disease, perhaps as many as $40 \%,{ }^{20}$ do not exhibit the traditional risk factors. Accordingly, a modification to this scoring has recently been sug- 
gested aiming to improve coronary artery disease risk assessment in asymptomatic people. It is conceivable that the use of serum biomarkers, especially C-reactive protein and atherosclerosis imaging, including coronary calcium scoring or carotid ultrasound for intima-media thickness, may refine risk estimation.

\section{DETECTION OF MYOCARDIAL ISCHEMIA}

There are several ways to detect myocardial ischemia by noninvasive methods in addition to clinical data as mentioned before. Although several diseases, such as congenital coronary anomalies, myocardial hypertrophy, and tumors, can cause myocardial ischemia, by far the most common cause is atherosclerosis. Therefore, in susceptible patients, the detection of myocardial ischemia usually implies atherosclerosis as the underlying disease. Germane to this scenario is the premise by which any noninvasive test should be interpreted.

According to the Bayes' theorem, the greater the prevalence of the disease in the population to which an individual belongs, the greater the validity of a positive test and likelihood that this is a true positive. Hence, in any population where there is a low likelihood of the condition being present, a positive result has limited value, being more likely a false positive. ${ }^{63}$

\section{RESTING AND EXERCISE STRESS TESTING}

Resting EKG is of limited value for ischemia recognition, since more often than not, it is normal. However, some specific findings are of great significance, such as signs of previous myocardial infarction, ST depression, and T wave inversion.

Conversely, stress EKG testing, either pharmacological or exercise based, is of considerable value and has been extensively studied in different populations; specific criteria for test interpretation have been developed based on comparative evolutive data. It is noteworthy that the majority of positive stress tests are false positives in unselected asymptomatic people ${ }^{63}$ because of the low pre-test probability of disease. Hence, the absolute risk of cardiac events in these populations remains low; consequently, the routine use of exercise ECG testing in completely unselected asymptomatic populations is not recommended. In contrast, a positive exercise test in middle-aged men with several coronary risk factors has independent predictive power for major coronary events. On the other hand, even in the presence of risk factors, the predictive power of a positive test is not the same for women and young adults because disease prevalence is low. ${ }^{63}$

\section{RESTING AND STRESS ECHOCARDIOGRAPHY}

Myocardial ischemia or infarction typically cause segmental myocardial dysfunction that can be detected by a 2-dimensional echocardiogram at rest. Areas of wall motion abnormalities, wall thinning, aneurysms, global ventricular dilation, increased ventricular volumes, and decreased ejection fraction can be indirect indicators of myocardial ischemia or necrosis. Given the ease with which an echocardiogram can be obtained, this method has considerable practical application in individual patients, especially those in whom exercise stress tests can not be performed.

Stress echocardiography is based on the principle that acute, induced myocardial ischemia leads to left ventricular dysynergy. It should be considered that the test adds costs and complexity to the exam. In a meta-analysis of 28 studies, the sensitivity and specificity of dobutamine stress echocardiography was $80 \%$ and $84 \%$, respectively, for detection of coronary artery disease. ${ }^{64}$ In addition, there is only limited data supporting the use of stress echocardiography as a tool to assess the intermediate-risk patient. ${ }^{65}$ However, stress echocardiography can be of value in certain patients in the intermediate-risk category, such as women and the elderly. Additional studies are needed to define its role for elevating such patients to the highrisk category for primary prevention.

\section{EXERCISE AND PHARMACOLOGICAL MYOCARDIAL PERFUSION IMAGING}

Myocardial perfusion scintigraphy is one of the most useful, widely used, and reliable methods for noninvasive myocardial ischemia detection or elimination. It also has a unique position as a tool for myocardial viability analysis. Its sensitivity is about $95 \%$, and its specificity reaches close to $90 \%$ in large series; ${ }^{66}$ its high negative predictive value of about $98 \%$ in asymptomatic individuals is of significant practical usefulness. Whether or not stress thallium scintigraphy can be a useful addition to exercise ECG testing for determining risk for major coronary events in intermediate-risk asymptomatic patients remains a critical question. Limited data suggest incremental value for this purpose in some populations, such as postmenopausal women and elderly men (age $>75$ years) in whom the use of exercise ECG testing is of limited applicability. Recently, Lima et $\mathrm{al}^{67}$ reported stress SPECT results in 328 patients aged 74 years or older. Abnormal results were common, particularly in men, in patients with chest pain, and in those with resting or exercise ST-T abnormalities. Patients with normal perfusion images had an annual hard event rate of $<1.0 \%$ per year, while those with abnormal images had a corresponding annual rate of $14.3 \%$ per year. 
Because few prognostic studies have included adequate numbers of asymptomatic people, data are scarce regarding the prognostic utility of noninvasive measures for the detection of myocardial ischemia in apparently asymptomatic people. With the exception of exercise ECG testing in asymptomatic men with increased cardiovascular risk profiles, few data exist to support the use of the noninvasive testing modalities. ${ }^{64}$

\section{DIRECT DETECTION OF ATHEROSCLEROTIC PLAQUE}

\section{Duplex ultrasound}

Duplex ultrasound is widely applicable for the early detection of atherosclerosis in the noninvasive vascular laboratory. Its major advantages include the simplicity and general availability of the procedure. Examination of the carotid arteries to measure the intima-media thickness is used routinely, and evaluation of plaques and even estimates of the degree of obstruction also are performed on a regular basis. Although plaque diameter is readily measurable, the variable and complex 3-dimensional morphology of plaques ${ }^{68}$ produces a poor correlation with actual plaque size or volume. Semiquantitative approaches include averaging of plaque diameters; the number of segments with plaques in the common carotid artery, bulb, internal carotid artery, and external carotid artery; or plaque number. Intima-media thickness correlates well with the extent of coronary lesions, and furthermore, as intima-media thickness increases, cardiovascular event rates also increase. ${ }^{68,69}$ Thus, in the Kuopio Ischemic Heart Disease Risk Factor Study, myocardial infarction risk increased by $11 \%$ for each 0.1 $\mathrm{mm}$ increase in common carotid intima-media thickness. ${ }^{70}$

Measurement of the ankle-brachial index with a handheld continuous-wave Doppler instrument is an accurate way to diagnose peripheral arterial disease. This is important not only for identifying patients with peripheral arterial disease but also because they frequently have atherosclerosis in other arterial territories and hence may have increased frequency of myocardial infarction and stroke. ${ }^{71}$

Duplex ultrasound may also be used to assess brachial artery reactivity, and therefore, endothelial function. ${ }^{22,72}$ As shown by Celermajer et al, ${ }^{21}$ brachial artery reactivity accurately reflects coronary reactivity and therefore can be used as a surrogate marker of coronary endothelial function. Endothelial dysfunction actually precedes clinical manifestations of coronary artery disease, is a better prognostic indicator of events than coronary lesions themselves, is associated with several risk factors, and can be improved by the correction of many classic risk factors such as hypercholesterolemia and arterial hypertension. ${ }^{73}$ However, long-term studies of endothelial function are still necessary to prove its relationship to coronary atherosclerosis and its value as predictor of events in asymptomatic individuals.

\section{ULTRA FAST COMPUTED TOMOGRAPHY - DETECTION OF THE AMOUNT OF CALCIUM}

Fast imaging is essential to overcome cardiac and respiratory motion artifacts; ultra fast computed tomography does just that. Only electron-beam computed tomography ${ }^{74}$ and fast-gated helical or spiral computed tomography ${ }^{75}$ can measure the amount or volume of calcium in blood vessels, although magnetic resonance imaging, $x$-ray angiography, and ultrasound can also identify calcified deposits in vessels. Atherosclerotic calcification may occur in early atherosclerotic lesions, it but is found more frequently and more extensively in advanced lesions. ${ }^{76} \mathrm{An}$ association between coronary calcium and coronary artery disease has been documented;, there is also evidence that the amount of coronary calcium is a predictor of risk of coronary events. ${ }^{77}$ According to a meta-analysis of data in asymptomatic populations, a calcium score above the population median value was associated with an unadjusted odds ratio of 4.2 (95\% confidence interval [CI] 1.6 to 11.3 ) for myocardial infarction or death. ${ }^{78}$ It is not certain, however, whether the predictive value of coronary calcification in high-risk subjects is superior to that of standard coronary risk factors ${ }^{79}$; given the cost and complexity of the test, this is a point of considerable practical interest. The additional benefit of using both coronary artery calcium scores plus the Framingham risk score was evaluated by Greenland et a ${ }^{80}$ in 1,461 asymptomatic, middle-aged ( $>45$ years) adults with at least 1 coronary risk factor; they were followed for 8.5 years after the computed tomography scan. A coronary artery calcium score $>300$ was predictive of myocardial infarction or coronary death; $(P<$ .001), compared with a score of zero. Moreover, coronary artery calcium scores were predictive of risk among patients with a Framingham risk score higher than $10 \%(P<.001)$ but not with a Framingham risk score lower than 10\%, suggesting that high coronary artery calcium scores can modify the predicted risk obtained from Framingham risk score alone, especially among patients in the intermediate-risk category. ${ }^{79}$ Figure 1 illustrates calcium scoring.

\section{CONTRAST-ENHANCED NONINVASIVE CORONARY ANGIOGRAPHY}

Noninvasive coronary angiography is performed after the intravenous administration of iodinated contrast agent, with EKG synchronization and during breath holding to minimize motion artifacts. Multiplanar reformat, maximum 


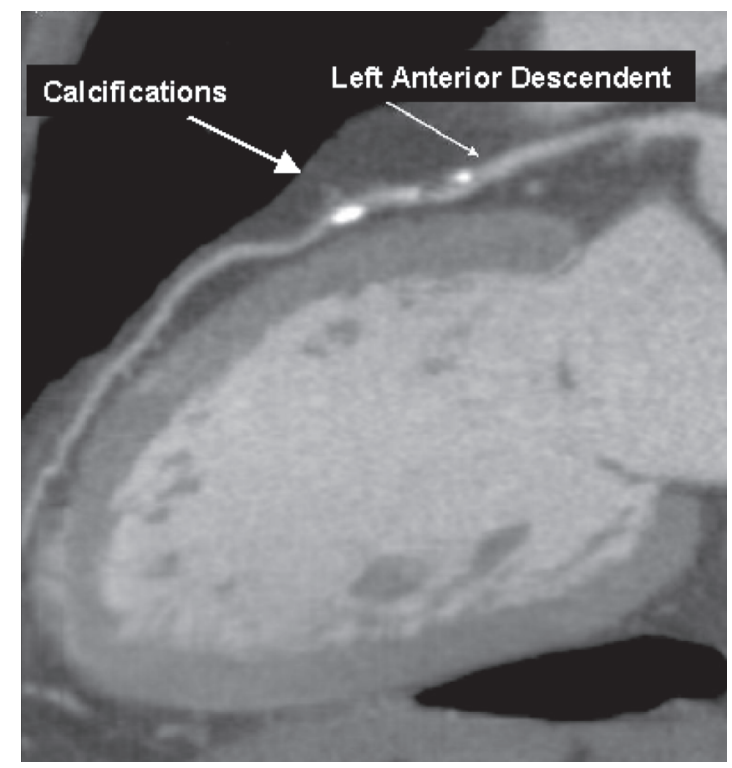

Figure 1 - Ultra fast multislice computer tomography of coronary arteries. Calcification of coronary, score 9.8 Agatston, ${ }^{80} 75^{\text {th }}$ percentile for age and gender

intensity projection, volume rendering, or virtual angioscopy can be performed and aid in the diagnosis of coronary stenosis. The technique is improving rapidly, and the newer generation 64-slice multidetector computer tomography will further refine diagnostic capability. Sensitivities of $89 \%$ to $92 \%$ and specificities of $93 \%$ to $98 \%$ have been recently reported, after the exclusion of arteries considered to be of subdiagnostic image quality. ${ }^{81,82}$

Although the diagnostic accuracy of noninvasive angiography regarding the degree of stenosis is still a matter of concern, this method may be satisfactory and convenient after percutaneous or surgical revascularization. Indeed, some studies show good results in detecting total occlusions but rather low sensitivity and specificity for identifying in-stent restenosis or saphenous vein graft lesions. ${ }^{83,84}$

The detection of noncalcified atherosclerotic plaques prone to rupture by computed tomography has also been tried with promising results. ${ }^{85,86}$ However, multidetector computed tomography underestimates plaque burden when compared to intravascular ultrasound, probably due to lower spatial resolution, especially in distal segments. ${ }^{87}$ Longterm observations regarding the predictive value of multidetector computed tomography are not available because of its relatively recent development; however, given its noninvasive nature and overall diagnostic precision, progressive use can be anticipated in the near future.

\section{MAGNETIC RESONANCE IMAGING}

Cardiac magnetic resonance imaging offers a unique, impressive range of information that has revolutionized the field of cardiac imaging. Through cardiac magnetic resonance, the dynamics of cardiac function can be appreciated in minute detail, and pathophysiological mechanisms became evident, forming the basis for clinical or surgical management of patients with known or suspected coronary artery disease. Cardiac magnetic resonance methods allow assessment of global and regional cardiac function, cardiac volumes, myocardial perfusion, cardiac valves, pericardium, myocardial viability, and proximal coronary anatomy, among others. Individually, these methods have shown promise as alternatives to the established tools for the noninvasive detection of coronary stenosis and myocardial infarction. ${ }^{88-90} \mathrm{~A}$ unique advantage of cardiac magnetic resonance imaging is that several of its methods can be combined in a single scanning session.

\section{CONTRAST-ENHANCED MAGNETIC RESONANCE ANGIOGRAPHY}

Noninvasive, accurate detection of coronary stenosis has been a challenge for quite some time. Recently, contrast-enhanced coronary magnetic resonance angiography was found to have high specificity and sensitivity compared with x-ray angiography for the detection of luminal narrowing $>50 \%$ in humans. ${ }^{89}$ Technical advances in processing speed and new contrast agents ${ }^{91,92}$ are partly responsible for the rapid evolution of the field. Imaging of large vessels, such as the aorta, carotid, and femoral arteries, is now routine and replaces conventional angiography, with unquestionable advantages. In addition, contrast-enhanced magnetic resonance angiography methodology has been proposed as a technique for the assessment of coronary anomalies, patency of bypass grafts, post-stent improvement in coronary flow, and coronary instent restenosis..$^{93-97}$

\section{HIGH-RESOLUTION MRI FOR PLAQUE CHARACTERIZATION}

Plaque destabilization is responsible for acute coronary syndromes and is a complex phenomenon characterized by inflammation, thrombosis, apoptosis, hemorrhage, and endothelial dysfunction that occur mostly in lipid-rich plaques. Magnetic resonance can differentiate plaque components with reasonable accuracy, based on biophysical and biochemical parameters such as chemical composition, water content, physical state, molecular motion, or diffusion. ${ }^{57}$ Thus far, magnetic resonance plaque characterization of the carotid arteries and aorta has proven to be very sensitive and specific as compared to that of the coronary arteries. ${ }^{98,99}$ A crucial ultimate goal of cardiovascular 
noninvasive imaging is to have reliable technology for plaque characterization of the coronary arteries. ${ }^{56}$

Magnetic resonance imaging is a new noninvasive method that can detect morphologic characteristics of coronary arteries in vivo in animals and humans and also allows the identification of arterial remodeling in experimental atherosclerosis. ${ }^{100-103}$ We have already detected by magnetic resonance imaging coronary vessel wall modifications, e.g., increases in wall thickness, vessel wall area, and total vessel area in patients with coronary artery disease compared to normal controls. ${ }^{104}$ Interestingly, the luminal area was preserved in these patients in spite of the presence of large plaque volumes (Figure 2). Thus, magnetic resonance imaging to determine the luminal area/total vessel area ratio is a noninvasive method for detecting coronary vessel wall modifications including remodeling and for clearly differentiating patients with coronary artery disease from healthy subjects despite a similar lumen (Figures 3a, 3b).

\section{IDENTIFYING THE UNSTABLE PATIENT}

The relationship between risk factors and the occurrence of atherosclerosis is unpredictable and variable. In general, it takes decades for risk factors to cause significant vessel obstruction and clinical syndromes. Although risk factors, and especially the clustering of 2 or more, will eventually lead to obstructive lesions, the time course of such events in any individual patient is far from predictable. Thus, some patients may have a slow clinical course over decades and finally present with typical effort angina due to flow-limiting stenosis, often affecting all coronary beds. On the other extreme, patients may present with acute coronary syndromes in their forties and fifties, with coronary lesions of moderate severity or even minor stenosis, due to destabilization of the plaque. Clearly then two different challenges must be faced if prevention of lesions on one hand and prevention of events on the other are to be

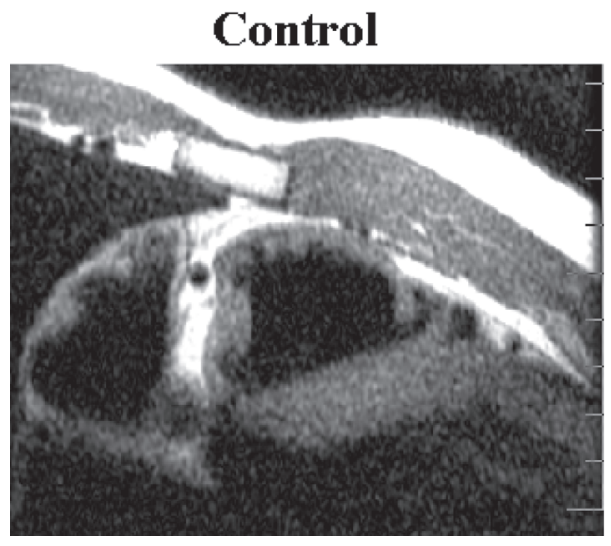

\section{Coronary plaque}

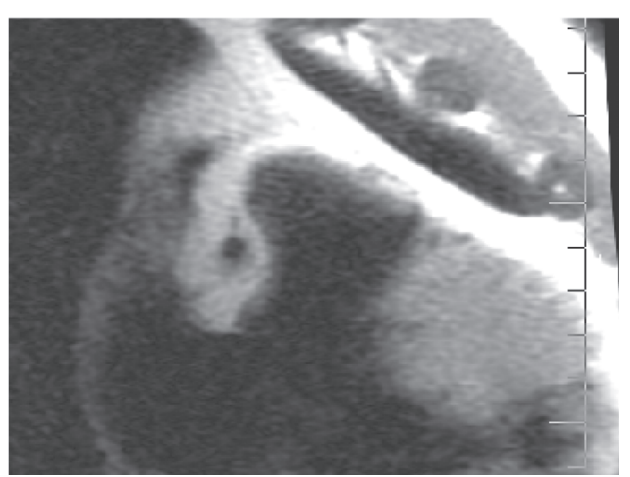

Figure 2 - Magnetic resonance of coronary arteries. Observe the increment of wall thickness and total vessel diameter of diseased vessel, a positive remodeling (right) compared to the control (left) ${ }^{104}$

Right Coronary Artery

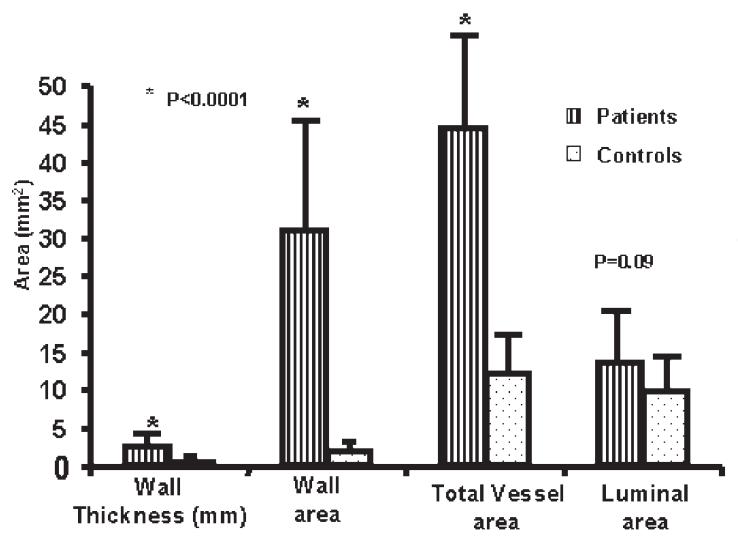

Left Anterior Descendent Artery

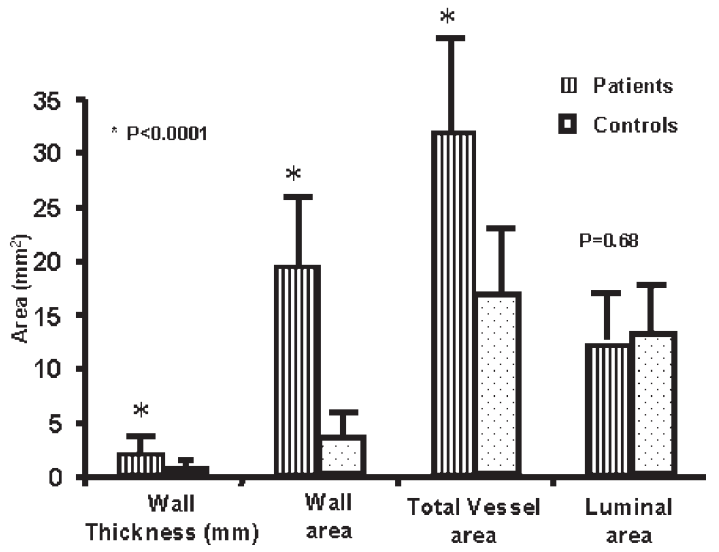

Figure 3a - Magnetic resonance of coronary arteries. Positive remodeling of coronary arteries indicated by increased wall thickness, wall area, and total vessel area with preservation of luminal area ${ }^{104}$ 


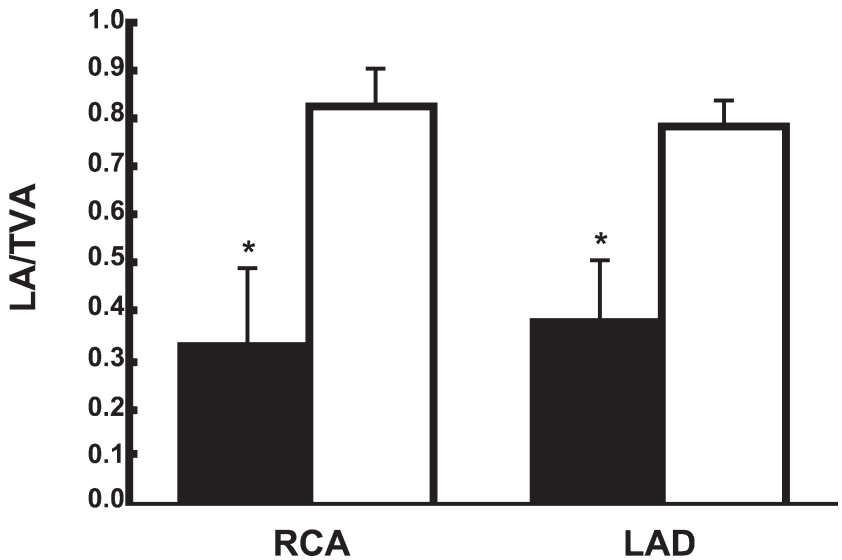

Figure 3b - LA/TVA ratio for the right coronary artery (RCA; left) and left anterior descending artery (LAD; right) of patients (filled columns) and controls (open columns). The reduced ratio for patients with coronary artery disease was due to vessel enlargement. ${ }^{*} \mathrm{p}<0.05$

achieved. Prevention of atherosclerosis development, the so-called primary prevention, is based on the recognition of risk factors and early identification of incipient lesions. For those individuals, the approaches for early detection of atherosclerosis were examined above. They need longterm preventive measures directed at controlling risk factors, such as recommendations for healthy lifestyles and eventually drug therapy, such as statins, aspirin, antihypertensives, or treatment for diabetes.

Identifying the unstable patient is an entirely different matter, because not everyone who has a plaque will soon have an event; conversely patients with even minor plaques may suffer acute events. For instance, analyzing 516 patients who were on a waiting list for coronary surgery, we observed that the most powerful indicators of complications in this period were angina, heart failure, and high triglyceride levels; coronary anatomy by itself was not a good predictor. ${ }^{105}$ This suggests that functional status, more than anatomy, is a fundamental determinant of prognosis.

In this regard, the challenge is to identify the unstable patient. Although inflammatory markers, coronary calcium scoring, magnetic resonance imaging, optical coherence tomography, angioscopic studies, thermography studies, and vascular ultrasonography have all been studied regarding their ability to identify such vulnerable patients, this still remains an elusive goal. ${ }^{106}$ Identification of "soft" plaques by noninvasive means would be critical. In this respect, magnetic resonance imaging is likely to have the greatest potential. Plaque analysis based on nanoparticles or gadolinium-tagged molecular imaging is being tested in noncoronary vascular beds, such as the distal aorta. ${ }^{107,108}$ Given the velocity of recent developments in this field, it may not be unrealistic to say we are in the dawn of the molecular plaque imaging era, which hopefully will improve our predictive ability.

These future developments will perfect our ability to identify not only incipient atherosclerosis but the vulnerable patient as well; then a more individualized approach for patient care can be adopted.

\section{RESUMO}

Luz PL da, Bertini PJ, Favarat D. Métodos não invasivos para identificação da doença aterosclerótica - desafios para prevenção da doença e eventos clínicos. Clinics. 2005;60(5):415-28.

A aterosclerose é uma doença inflamatória crônica que afeta essencialmente todas as artérias incluindo a aorta, coronárias, carótidas e artérias periféricas. É a causa principal de morte no hemisfério ocidental, devido as síndromes cardiovasculares, tais como o infarto do miocárdio, insuficiência cardíaca e acidentes cerebrovasculares.

Quantidades enormes de recursos econômicos e humanos são usadas em tratamentos de suas complicações, inclusive estudos de imagem, cirurgias coronárias, intervenções com cateteres, marcapasso e tratamentos médicos. Tratar complicações, entretanto, são ações a posteriori.

Uma alternativa melhor seria prevenir o desenvolvimento da aterosclerose, ou pelo menos identificar os pacientes que tenham risco de eventos agudos e intervir antes de sua ocorrência.

O objetivo desta revisão é discutir o valor prognóstico dos fatores de riscos tradicionais e emergentes, e o papel dos métodos diagnósticos não invasivos para a doença coronária - teste de esforço, eco estresse, ultra-sonografia dúplex, tomografia computadorizada e a ressonância magnética. A combinação de marcadores biológicos e de métodos não invasivos, é de grande utilidade na identificação precoce da doença aterosclerótica. Futuros desenvolvimentos logo aperfeiçoarão nossa capacidade de identificar o paciente vulnerável e nos permitir um manejo mais individualizado.

UNITERMOS: Aterosclerose. Lípides. Doença coronária. Testes de diagnóstico. Imagem diagnóstica, cardiovascular. 


\section{REFERENCES}

1. Ross R. Atherosclerosis: an inflammatory disease. N Engl J Med. 1999;340:115-26.

2. Libby P. Inflammation in atherosclerosis. Nature. 2002;420:868-74.

3. Szmitko PE, Wang CH, Weisel RD, de Almeida JR, Anderson TJ, Verna S. New markers of inflammation and endothelial cell activation: Part I. Circulation. 2003;108:1917-23.

4. Szmitko PE, Wang CH, Weisel RD, Jeffries GA, Anderson TJ, Verma S. Biomarkers of vascular disease linking inflammation to endothelial activation Part II. Circulation. 2003;108:2041.

5. Lindstedt KA, Leskinen MJ, Kovanen PT. Proteolysis of the pericellular matrix: a novel element determining cell survival and death in the pathogenesis of plaque erosion and rupture. Arterioscler Thromb Vasc Biol. 2004;24:1350-58.

6. Moreau M, Brocheriou I, Petit L, Nino E, Chapman MJ, Rouis M. Interleukin (IL)-8 mediates downregulation of tissue inhibitor of metalloproteinases-I expression in cholesterol-loaded human monocyte-derived macrophages: relevance to stability of atherosclerotic plaque. Circulation. 1999;99:420-6.

7. Xu XP, Meisel SR, Ong JM, Kaul S, Cercek B, Rajavashisth TB, et al Oxidized low-density lipoprotein regulates matrix metalloproteinase9 and its tissue inhibitor in human monocyte-derived macrophages. Circulation. 1999;99:993-8.

8. Mansur AP, Souza MFM, Favarato D, Avakian SD, Cesar LAM, Aldrigui JM, et al. Stroke and ischemic heart disease mortality trends in Brazil from 1979 to 1996. Neuroepidemiology. 2003;22:179-83.

9. Spence JD, Hegele RA. Noninvasive phenotypes of atherosclerosis: similar windows but different views. Stroke 2004;35:649.

10. Lloyd-Jones DM, Nam BO, D’Agostino RB, Levy D, Murabito JM, Wang TJ, et al. Parental cardiovascular disease as a risk factor for cardiovascular disease in middle-aged adults. A prospective study of parents and offspring. JAMA. 2004;291:2204-11.

11. Enos WF, I-Holmes RH, Beyer J. Coronary disease among United States soldiers killed in action in Korea: preliminary report. JAMA. $1953 ; 152: 1090-3$

12. McNamara JJ, Molot MA, Stremple JF, Cutting RT. Coronary artery disease in combat casualties in Vietnam. JAMA. 1971;216:1185-7.

13. Berenson GS, Srinivasan SR, Bao W, Newman WP 3rd, Tracy RE, Wattigney WA. Association between multiple cardiovascular risk factors and atherosclerosis in children and young adults. The Bogalusa Heart Study. N Engl J Med. 1998;338:1650-6.

14. Atherosclerosis in Youth (PDAY) Research Group. Relationship of atherosclerosis in young men to serum lipoprotein cholesterol concentrations and smoking. A preliminary report from the Pathobiological Determinants of Atherosclerosis in Youth (PDAY). JAMA. 1990;264:3018-24.

15. Joszeph A, Acekrman D, Talley JD, Johnstone J, Kyupersmith J. Manifestations of coronary atherosclerosis in young trauma victims an autopsy study. J Am Coll Cardiol. 1993;22:59-67.

16. Glagov S, Weisenberg E, Zarins CK, Stankunavicius R, Kolettis GJ. Compensatory enlargement of human atherosclerotic coronary arteries. N Engl J Med. 1987;316:1371-5.
17. Ambrose JA, Tannenbaum MA, Alexopoulos D, Hjemdahl-Monsen CE, Leavy J, Weiss M, et al. Angiographic progression of coronary artery disease and the development of myocardial infarction. J Am Coll Cardiol 1988;12:56-62.

18. Libby P. Molecular bases of the acute coronary syndromes. Circulation. 1995;91:2844-50.

19. Falk E, Shah PK, Fuster V. Coronary plaque disruption. Circulation. 1995;92:657-71.

20. Khot UN, Khot MB, Bajzer CT, Sapp SK, Ohman EM, Brener SJ, et al. Prevalence of conventional risk factors in patients with coronary heart disease. JAMA. 2003;290:898-904.

21. Kannel WB, Sorlie P, McNamara PM. Prognosis after initial myocardial infarction: the Framingham study. Am J Cardiol. 1979;44:53-9.

22. Celemajer DS, Sorensen KE, Bull C, Robinson J, Deanfiled JE. Endothelium-dependent dilation in the systemic arteries of asymptomatic subjects relates to coronary risk factors and their interaction. J Am Coll Cardiol. 1994;24:1468-74.

23. Rembold KE, Ayers CR, Wills MB, Rembold CM. Usefulness of carotid intimal medial thickness and flow-mediated dilation in a preventive cardiovascular practice. Am J Cardiol. 2003;91:1475-7.

24. Anderson KM, Odell PM, Wilson PWF, Kannel WB. Cardiovascular disease risk profiles. Am Heart J. 1990;121:293-8.

25. Wilson PWF, D'Agostino RB, Levy D, Belanger AM, Silbershatz H, Kannel WB. Prediction of coronary heart disease using risk factor categories. Circulation. 1998;97:1837-47.

26. Conroy RM, Pyorala K, Fitzgerald AP, Sans A, Menotti A, De Backer $\mathrm{G}$, et al: the SCORE project group. Estimation of ten-year risk of fatal cardiovascular disease in Europe: the SCORE project. Eur Heart J. 2003;24,987-1003.

27. Kannel WB, McGee D, Gordon T. A general cardiovascular risk profile: the Framingham Study. Am J Cardiol 1976;38:46-51.

28. Haffner SJ, Cassells H. Hyperglycemia as a cardiovascular risk factor. Am J Med. 2003;115(Suppl 8A):6S-11S.

29. Kullo IJ, Cassidy AE, Peyser PA, Turner ST, Sheedy PF 2nd, Bielak LF Association between metabolic syndrome and subclinical coronary atherosclerosis in asymptomatic adults. Am J Cardiol. 2004;94:1554-8.

30. Gotto AM Jr, Grundy SM. Lowering LDL cholesterol: questions from recent meta-analyses and subset analyses of clinical trial DataIssues from the Interdisciplinary Council on Reducing the Risk for Coronary Heart Disease, ninth Council meeting. Circulation. 1999;99:E1-7

31. Austin MA, Breslow JL, Hennekens CH, Buring JE, Willet WC, Krauss RM. Low-density lipoprotein subclass patterns and risk of myocardial infarction. JAMA. 1988;260:1917-21.

32. Carmena R, Duriez P, Fruchart JC. Atherogenic lipoprotein particles in atherosclerosis. Circulation. 2004;109(23 Suppl 1)III2-7.

33. Gordon T, Castelli WP, Hjortland MC, Kannel WB, Dawber TR. High density lipoprotein as a protective factor against coronary heart disease. The Framingham Study. Am J Med. 1977;62:707-14. 
34. Benjo AM, Maranhao RC, Coimbra SR, Andrade ACM, Favarato D, Molina MS, et al. Accumulation of chylomicron remnants and impaired vascular reactivity occurs in subjects with isolated low HDL cholesterol: effects of niacin treatment. Atherosclerosis. 2005 (in press).

35. Hokanson JE, Austin MA. Plasma triglyceride level is a risk factor for cardiovascular disease independent of high-density lipoprotein cholesterol level: a meta-analysis of population-based prospective studies. J Cardiovasc Risk. 1996;3:213-9.

36. Assmann G, Cullen P, Schulte H. The Munster Heart Study (PROCAM). Results of follow-up at 8 years. Eur Heart J. 1998;19 (Suppl A):A211.

37. Hodis HN, Mack WJ, Azen SP, Alaupovic P, Pogoda, JM, La Bree L, et al. Triglyceride- and cholesterol-rich lipoproteins have a differential effect on mild/moderate and severe lesion progression as assessed by quantitative coronary angiography in a controlled trial of lovastatin. Circulation. 1994;90:42-9.

38. Schaefer EJ, McNamara JR, Shah PK, Najima K, Cuples LA, Ordovas $\mathrm{JM}$, et al. Elevated remnant-like particle cholesterol and triglyceride levels in diabetic men and women in the Framingham Offspring Study. Diabetes Care. 2002;25:989-94.

39. Da Luz PL, Cesena FHY, Favarato D, Cerqueira ES. Comparison of serum lipid values in patients with coronary disease $<50,50-59,60$ 69 and $>70$ years of age. Am J Cardiol. 2005 (in press).

40. Hanak V, Munoz J, Teague J, Stanley A Jr, Bittner V. Accuracy of the triglyceride to high-density lipoprotein cholesterol ratio for prediction of the low-density lipoprotein phenotype B. Am J Cardiol. 2004;94:219-22.

41. Friesinger GC, Page EE, Ross RS. Prognostic significance of coronary arteriography. Trans Assoc Am Physicians. 1970;83:78-92.

42. Da Luz PL, Favarato D, Faria Neto JR, Chagas ACP, Lemos P. Perfil lipídico e extensão da doença arterial coronária: valor da relação triglicéride/HDL-colesterol XVI Congresso da Sociedade de Cardiologia do Estado de São Paulo, Campos do Jordão, São Paulo, Brasil, 2005, abstract: 243.

43. Yamashita H, Shimada K, Seki E, Mokuno H, Daida H. Concentrations of interleukins, interferon, and C-reactive protein in stable and unstable angina pectoris. Am J Cardiol 2003;91:133-6.

44. Van der Meer I, de Maat MP, Bots ML, Breteler MM, Mijer J, Kiliaan AJ, Hofman A, Wittemannet, JC. Inflammatory mediators and cell adhesion molecules as indicators of severity of atherosclerosis: the Rotterdam Study. Arterioscler Thromb Vasc Biol. 2002;22:838-42.

45. Wang TJ, Larson MG, Levy D, Benjamin EJ, Kupka MJ, Manning $\mathrm{WJ}$, et al. C-reactive protein is associated with subclinical epicardial coronary calcification in men and women: the Framingham Heart Study. Circulation. 2002;106:1189-91.

46. Burke AP, Tracy RP, Kolodgie F, Malcom GT, Zieske A, Kutys R, et al. Elevated C-reactive protein values and atherosclerosis in sudden coronary death: association with different pathologies. Circulation. 2002;105:2019-23.

47. Ridker PM, Stampfer MJ, Rifai N. Novel risk factors for systemic atherosclerosis: a comparison of C-reactive protein, fibrinogen, homocysteine, lipoprotein (a), and standard cholesterol screening as predictors of peripheral arterial disease. JAMA. 2001;285:2481-5.
48. Ridker PM, Morrow DA, Rose LM, Rifai N, Cannon P, Braunwald E Relative efficacy of atorvastatin $80 \mathrm{mg}$ and pravastatin $40 \mathrm{mg}$ in achieving the dual goals of low-density lipoprotein cholesterol $<70$ $\mathrm{mg} / \mathrm{dl}$ and C-reactive protein $<2 \mathrm{mg} / \mathrm{l}$ : an analysis of the PROVE-IT TIMI-22 trial. J Am Coll Cardiol. 2005;45:1644-8.

49. Pearson TA, Mensah GA, Alexander RW, Anderson JL, Cannon RO $3^{\text {rd }}$, Criqui RM. Markers of inflammation and cardiovascular disease: application to clinical and public health practice. A statement for healthcare professionals from the Centers for Disease Control and Prevention and the American Heart Association. Circulation. 2003;107:499-511.

50. Muir KW, Weir CJ, Alwan W, Squire IB, Lees KR. C-reactive protein and outcome after ischemic stroke. Stroke. 1999;30:981-5.

51. Irribarren C, Gross MD, Darbinian JA, Jacobs DR, Siney S, Loria CM Association of lipoprotein-associated phospholipase A2 mass and activity with calcified coronary plaque in young adults: the CARDIA study. Arterioscler Thromb Vasc Biol. 2005;216-21.

52. Faria Neto JR, Chagas ACP, Bydlowski SP, Lemos Neto PA, Chamone DA, Ramires JAF, et al. Hyperhomocysteinemia, but not MTHFR C677T polymorphism, is an independent risk factor with a graded relation to the extent of coronary disease in a population highly susceptible to nutritional deficiencies. Braz J Med Biol Res. 2005 (in press).

53. Bostom AG, Silbershatz H, Rosenberg IH, Selhub J, D'Agostino RB Wolf PA, et al. Nonfasting plasma total homocysteine levels and allcause and cardiovascular disease mortality in elderly Framingham men and women. Arch Intern Med. 1999;159:1077-80.

54. Folsom AR, Nieto FJ, McGovern PG, Tsay MY, Mallinow MR, Eckfeldit JH, et al. Prospective study of coronary heart disease incidence in relation to fasting total homocysteine, related genetic polymorphisms, and $\mathrm{B}$ vitamins: the Atherosclerosis Risk in Communities (ARIC) study. Circulation. 1998;98:204-10.

55. Wang TJ, Larson MG, Levy D, Benjamin EJ, Leip EP, Omland T, et al Plasma natriuretic peptide levels and the risk of cardiovascular events and death. N Engl J Med. 2004;350:655-63.

56. Lemos JA, Morrow DA, Bentley JH, Omland T, Sabatine MS, McCabe $\mathrm{CH}$, et al. The prognostic value of b-type natriuretic peptide in patients with acute coronary syndromes. N Engl J Med. 2001;345:1014-21.

57. Moreno PR, Fuster V. The year in atherothrombosis. J Am Coll Cardiol 2004;44:2099-110.

58. Varo N, de Lemos JA, Libby P, Morrow DA, Murphy AS, Nuzzo R, et al. Soluble CD40L: risk prediction after acute coronary syndromes. Circulation. 2003;108:1049-52.

59. Greenland P, Smith JS Jr, Grundy SM. Improving coronary heart disease risk assessment in asymptomatic people: role of traditional risk factors and noninvasive cardiovascular tests. Circulation. 2001;104:1863-7.

60. Smith SC Jr, Amsterdam E, Balady GJ, Bonow RO, Fletcher GF Froelicher V, et al. Prevention Conference V: beyond secondary prevention: identifying the high-risk patient for primary prevention: tests for silent and inducible ischemia: Writing Group II. Circulation. 2000;101:E12-6.

61. Yusuf S, Hawken S, Ounpuu S, Dans T, Avezum A, Lanas F, et al. INTERHEART study investigators. Effect of potentially modifiable risk factors associated with myocardial infarction in 52 countries (the INTERHEART study): case-control study. Lancet. 2004;364:937-52. 
62. Executive summary of the third report of the national cholesterol education program (NCEP). Expert panel on detection, evaluation, and treatment of high blood cholesterol in adults (Adult Treatment Panel III). JAMA. 2001;285:2486-97.

63. Pasternak RC, Abrams J, Greenland P, Smaha LA, Wilson PW, Hounston-Miller N. Task Force \#1-Identification of coronary heart disease risk: Is there a detection gap? J Am Coll Cardiol. 2003;41:1855917.

64. Armstrong WF, Zoghbi WA. Stress echocardiography: currrent methodology and clinical applications. J Am Coll Cardiol. 2005;45: 1739-4765.

65. Smith-Jr SC, Greenland P, Grundy SM. Prevention conference v. beyond secondary prevention: identifying the high-risk patient for primary prevention-Executive Summary. Circulation. 2000;101:111 16.

66. Underwood SR, Anagnostopoulos C, Cerqueira M, Ell EJ, Harbinson $\mathrm{M}$, Kellon AD, et al. British cardiac society, british nuclear cariology society, british nuclear medicine society, royal college of physician of london, royal college of radiologist. Perfusion scintigraphy: the evidence. Eur J Nucl Med Mol. Imaging 2004;31:261-91.

67. Lima RSL, De Lorenzo A, Pantoja MR, Siqueira A. Incremental prognostic value of myocardial perfusion 99m-technetium-sestamibi SPECT in the elderly. Int J Cardiol. 2004;93:137-43.

68. O’Leary DH, Polak JF, Kronmal RA, Manolio TA, Burque GL, Wolfson SKJr. Carotid-artery intima and media thickness as a risk factor for myocardial infarction and stroke in older adults: Cardiovascular Health Study Collaborative Research Group. N Engl J Med. 1999;340:14-22.

69. Redberg RF, Vogel RA, Criqui MH, Herrington DM, Lima JA, Roman MJ. Task Force \#3-what is the spectrum of current and emerging techniques for the noninvasive measurement of atherosclerosis? J Am Coll Cardiol. 2003;41:1855-917.

70. Salonen JT, Salonen R. Ultrasound B-mode imaging in observational studies of atherosclerotic progression. Circulation. 1993;87 Suppl II:56-65.

71. Criqui MH, Langer RD, Fronek A, Feigelson HS, Klauber MR, McCann TJ, et al. Mortality over a period of 10 years in patients with peripheral arterial disease. N Engl J Med. 1992;326:381-6.

72. Corretti MC, Anderson TJ, Benjamin EJ, Celermager D, Charbonneau F, Creager MA, et al. Guidelines for the ultrasound assessment of endothelial-dependent flow-mediated vasodilation of the brachial artery: a report of the International Brachial Artery Reactivity Task Force [published correction appears in J Am Coll Cardiol. 2002;39:1082]. J Am Coll Cardiol 2002;39:257-65.

73. Da Luz PL, Favarato D. A disfunção endotelial como índice prognóstico e alvo terapêutico, in Da Luz PL, Laurindo FRM e Chagas ACP. Endotélio e doenças cardiovasculares. Atheneu, São Paulo, 2003:203-20.

74. Callister TQ, Raggi P, Cooil B, Lippolis NJ, Russo DJ, et al. Effect of HMG-CoA reductase inhibitors on coronary artery disease as assessed by electron-beam computed tomography. N Engl J Med. 1998;339:1972-8.

75. Becker CR, Kleffel T, Crispin A, Kiness A, Young J, Schoepf UJ, et al. Coronary artery calcium measurement: agreement of multirow detector and electron beam CT. Am J Roentgenol. 2001;176:1295-8.
76. Wexler L, Brundage B, Crouse J, Detrano R, Fuster V, Madahi J, et al. Coronary artery calcification: pathophysiology, epidemiology, imaging methods, and clinical implications. A statement for health professionals from the American Heart Association Writing Group. Circulation. 1996;94:1175-92.

77. Raggi P, Callister TQ, Cooil B, He ZX, Lippolis NJ, Patterson RE, et al. Identification of patients at increased risk of first unheralded acute myocardial infarction by electron-beam computed tomography. Circulation. 2000;101:850-5.

78. O’Malley PG, Taylor AJ, Jackson JL, Doherty TM, Detrano RC. Prognostic value of coronary electron-beam computed tomography for coronary heart disease events in asymptomatic populations. Am J Cardiol. 2000;85:945-8.

79. O'Rourke RA, Brundage BH, Froelicher VF, Greenland P, Grundy SM, Hachamovit R, et al. American College of Cardiology/ American Heart Association Expert Consensus document on electron-beam computed tomography for the diagnosis and prognosis of coronary artery disease. Circulation. 2000;102:126-40.

80. Greenland P, LaBree L, Azen SP, Doherty TM, Detrano RC, et al Coronary artery calcium score combined with Framingham score for risk prediction in asymptomatic individuals. JAMA. 2004;291:210-5.

81. Ropers D, Baum U, Pohle K, Anders K, Uhlzeimer S, Ohnesorge B, et al. Detection of coronary artery stenoses with thin-slice multi-detector row spiral computed tomography and multiplanar reconstruction. Circulation. 2003;107:664-6.

82. Martuscelli E, Romagnoli A, D'Eliseo A, Razzini C, Tomassini M, Sperandio M, et al. Accuracy of thin-slice computed tomography in the detection of coronary stenoses. Eur Heart J. 2004;25:1043-8.

83. Nieman K, Pattynama PM, Rensing BJ, Van Geuns RJ, De Feyter PJ. Evaluation of patients after coronary artery bypass surgery: CT angiographic assessment of grafts and coronary arteries. Radiology. 2003;229:749-56

84. Kruger S, Mahnken AH, Sinha AM, Borgans A, Dedden K, Hoffman $\mathrm{R}$, et al. Multislice spiral computed tomography for the detection of coronary stent restenosis and patency. Int J Cardiol. 2003;89:167-72.

85. Caussin C, Ohanessian A, Lancelin B, Rahal S, Hennequin R, Dambrim $\mathrm{G}$, et al. Coronary plaque burden detected by multislice computed tomography after acute myocardial infarction with near-normal coronary arteries by angiography. Am J Cardiol. 2003;92:849-52

86. Schroeder S, Kuettner A, Kopp AF, Heushimdt M, Burgsthaler C, Herdeg C, et al. Noninvasive evaluation of the prevalence of noncalcified atherosclerotic plaques by multi-slice detector computed tomography: results of a pilot study. Int J Cardiol. 2003;92:151-5.

87. Leber AW, Knez A, Becker A, von Ziegler F, Nikolaou K, Rist C, et al. Accuracy of multidetector spiral computed tomography in identifying and differentiating the composition of coronary atherosclerotic plaques: a comparative study with intracoronary ultrasound. J Am Coll Cardiol. 2004;43:1241-7.

88. Stuber M, Botnar RM, Danias PG, Sodickson DK, Kissinger KV, Van Cauterem M, et al. Double-oblique free-breathing high resolution three-dimensional coronary magnetic resonance angiography. J Am Coll Cardiol. 1999;34:524-31.

89. Kim WY, Danias PG, Stuber M, Flamm SD, Plein S, Nagel E, et al. Coronary magnetic resonance angiography for the detection of coronary stenoses. N Engl J Med. 2001;345:1863-9. 
90. Regenfus M, Ropers D, Achenbach S, Schlundt C, Kessler W, Laub G, et al. Diagnostic value of maximum intensity projections versus source images for assessment of contrast- enhanced three-dimensional breathhold magnetic resonance coronary angiography. Invest Radiol. 2003:38:200-6

91. Yang PC, Meyer CH, Terashima M, Kaji S, McConnel MV, Makovski A, et al. Spiral magnetic resonance coronary angiography with rapid real-time localization. J Am Coll Cardiol. 2003;41:1134-41.

92. Klein C, Schalla S, Schnackenburg B, Bornstted A, Hoffman V, Fleck $\mathrm{E}$, et al. Improvement of image quality of non-invasive coronary artery imaging with magnetic resonance by the use of the intravascular contrast agent Clariscan (NC100150 injection) in patients with coronary artery disease. J Magn Reson Imaging. 2003;17:656-62.

93. Bunce NH, Lorenz CH, Keegan J, Lesser J, Reyes EM, Firminn DN, et al. Coronary artery anomalies: assessment with free-breathing threedimensional coronary MR angiography. Radiology. 2003;227:201-8.

94. Bunce NH, Lorenz CH, John AS, Lesser JR, Mohiadding RH, Pennel DJ. Coronary artery bypass graft patency: assessment with true ast imaging with steady-state precession versus gadolinium-enhanced MR angiography. Radiology. 2003;227:440-6.

95. Langerak SE, Vliegen HW, Jukema JW, Zwinderman AH, Lamb HJ, de Ross A, et al. Vein graft function improvement after percutaneous intervention: evaluation with MR flow mapping. Radiology. 2003;228:834-41.

96. Nagel E, Thouet T, Klein C, Schalla S, Bornstedt A, Schnackenburg B, et al. Noninvasive determination of coronary blood flow velocity with cardiovascular magnetic resonance in patients after stent deployment. Circulation. 2003;107:1738-43.

97. Corti R, Fuster V, Fayad ZA, Worthley SG, Helft G, Smith D, et al. Lipid lowering by simvastatin induces regression of human atherosclerotic lesions: two years' follow-up by high-resolution noninvasive magnetic resonance imaging. Circulation. 2002;106:28847.

98. Yuan C, Zhang SX, Polissar NL, Echelard D, Ortis G, Davis JW, et al. Identification of fibrous cap rupture with magnetic resonance imaging is highly associated with recent transient ischemic attack or stroke. Circulation. 2002;105:181-5.
99. Worthley SG, Helft G, Fuster V, Fayad ZA, Shinnar M, Minkoff LA, et al. Noninvasive in vivo magnetic resonance imaging of experimental coronary artery lesions in a porcine model. Circulation. 2000;101:2956-61.

100. Fayad ZA, Fuster V, Fallon JT, Jayasundera T, Wortley SG, Helft G, et al. Noninvasive in vivo human coronary artery lumen and wall imaging using black-blood magnetic resonance imaging. Circulation. 2000;102:506-10.

101. Botnar RM, Stuber M, Kissinger KV, Kim VY, Spuentrup E, Manning WJ. Noninvasive coronary vessel wall and plaque imaging with magnetic resonance imaging. Circulation. 2000;102:2582-7.

102. Fayad ZF, Fallon JT, Shinnar M, Wehrli S, Dansky HM, Poon M, et al. Noninvasive in vivo high-resolution magnetic resonance imaging of atherosclerotic lesions in genetically engineered mice. Circulation. 1998;98:1541-7.

103. Worthley SG, Helft G, Fuster V, Zaman AG, Fayad ZA, Fallon JT, et al. Serial in vivo MRI documents arterial remodeling in experimental atherosclerosis. Circulation. 2000;101:586-9.

104. Bertini PJ, Parga JR, Chagas ACP, Da Luz PL. Compensatory enlargement of human coronary arteries identified by magnetic resonance imaging. Braz J Med Biol Res. 2005;38:661-7.

105. Cesena FHY, Favarato D, Cesar LAM, Da Luz, PL. Cardiac complications during waiting for elective coronary artery bypass graft surgery: incidence, temporal distribution and predictive factors. Eur J Cardiothoracic Surg. 2004;25:196-202.

106. Madjid M, Zarrabi A, Litovsky S, Willerson JT, Casscells W. Finding vulnerable atherosclerotic plaques: is it worth the effort? Arterioscler Thromb Vasc Biol. 2004;24:1775-82.

107. Yu X, Song SK, Chen J, Scott MJ, Fuhrhop RJ, Hall CS, et al. Highresolution MRI characterization of human thrombus using a novel fibrin-targeted paramagnetic nanoparticle contrast agent. Magn Reson Med. 2000;44:867-72.

108. Kramer CM, Cerilli LA, Hagspiel K, DiMaria JM, Epstein FH, Kern JA. Magnetic resonance imaging identifies the fibrous cap in atherosclerotic abdominal aortic aneurysm. Circulation. 2004;109:1016-21. 